\title{
Benchmarking of Solar PV performance ratio among different regions in Peru: sample of five small-scale systems.
}

\author{
Caroline Camarena-Gamarra ${ }^{1}$, José Calle-Maravi, Ph.D. ${ }^{2}$, Johnny Nahui-Ortiz, Ph.D. ${ }^{1}$ \\ ${ }^{1}$ National University of Engineering, Peru, ccamarenag@uni.pe, jnahuio@uni.edu.pe \\ ${ }^{2}$ National Agrarian University La Molina, Peru, jcalle@lamolina.edu.pe
}

\begin{abstract}
Five 3.25-kWp Photovoltaic Systems were installed in different regions in Peru. Solar irradiance and power output were measured during the entire year of 2019. Based on data registered, solar photovoltaic ( $P V$ ) performance ratio was assessed for all systems.

Analysis of how a variation of the solar irradiation and the power output may affect Levelized Cost Of Energy (LCOE) values was carried out. Implications for end users in terms of expected payback time due to different LCOE values were also assessed.

It is concluded that Performance Ratio changes over the year depending on which of the five regions the PV system was installed. Considering average monthly values, calculated for over a year, the highest value corresponds to Site Number 3 (Piura) while the lowest value corresponds to Site Number 2 (Lima Agrarian National University La Molina, UNALM).

If LCOE from site Number 3 is considered as a basis for comparison purposes, then LCOE from site Number 2 would be $78.5 \%$ more expensive in terms of US\$ $/ \mathrm{kWh}$. Also, if payback time from site Number 3 is considered as a basis for comparison purposes, then payback time from site Number 2 would be $78.5 \%$ longer.

Therefore, expected performance of a solar PV system, among different regions of the country, is a factor that should be considered when proposing policies and incentives for net metering squemes under distributed generation.
\end{abstract}

Keywords-Education Facility, PV System, Performance Ratio, Solar Energy, Environmental Management.

\section{INTRODUCTION}

Net metering based on solar on-grid PV systems at small scale is getting increased attention worldwide. In Peru, such squeme has not yet been implemented but expectations are high. In October 2015, Law Decree Nr 1221 stated an official definition for Distributed Generation; however, regulations for its commercial introduction are still in progress.

A few small scale on-grid solar PV systems were installed in university campuses located in different regions of Peru. Using their embedded monitoring system, solar PV energy production, as well as solar irradiation, have been monitored all year long. The research group is interested here in finding out how a solar PV system with the same installed capacity, connected to the grid, would perform under different weather conditions. And, how the variations in electricity production would affect the end user in terms of expected payback for the implementation of such a solar PV system.

Digital Object Identifier (DOI):

http://dx.doi.org/10.18687/LACCEI2020.1.1.245

ISBN: 978-958-52071-4-1 ISSN: 2414-6390

\section{BACKGROUND}

In Ref. [1], energy security is the triggering factor for a developing country. Thus, for ensuring energy security renewable energy such as PV plant could be a best alternative. This study deals with the performance analysis of $80 \mathrm{kWp}$ grid-connected solar power plant in Dhaka. The accuracy of predicted solar irradiation will affect the power output forecast of grid-connected photovoltaic systems which is important for power system operation and planning.

In Ref. [2], this case study presents the performance of a megawatt-scale grid-connected rooftop solar photovoltaic (PV) plant installed on the building rooftops of an educational institute. A framework is proposed to validate the existing simulation models that are used for PV project modelling. The validation is done by comparing the simulated performance with the real-time monitored performance. Based on the monitored data and by following the proposed framework, performance analysis is carried out. The results include the estimated parameters like energy outputs, yield factor, capacity factor, performance ratio, and the error matrices. Overall, it is observed that there is a deviation between the simulated and monitored energy performance.

In Ref. [3], Energy produced from a typical PV panel with or without solar tracker is mainly dependent on the available solar irradiance. Interestingly, for some locations on nearly the same latitude in the northern hemisphere, the solar irradiance varies significantly resulting to change in the ranking pattern of solar PV trackers. For this reason, the present study aims to explore the effect of solar irradiation on the technical and economic performance of PV panels incorporated with different solar trackers. The performance metric indicators of the energy gain and levelized cost of electricity (LCOE) are utilized to depict the most preferred solar tracking option for implementation in those regions. Overall, the observed ranking patterns are expected to guide not only solar PV project designers and engineers but also policymakers in the selection and implementation of suitable trackers in the regions.

In Ref. [4], the solar irradiation is one the most critical parameter to ensure the overall profitability of photovoltaic (PV) projects. The present paper evaluates how reported changes in solar irradiation have affected both PV projects profitability and overall costs of subsidy for final consumers. By focusing on a large sample of Italian PV plants, our findings highlight that solar irradiation levels higher than 
those initially assumed have caused excessive rents and windfall profits for PV project developers thus potentially harming electricity users which are indirectly bearing the burden of the renewable energy sources (RES) incentives. In regulatory contexts suffering from information asymmetries between RES producers and regulatory agencies, support tariff set by public authorities should be periodically revised according to transparent procedures, whenever significant changes in long-term solar irradiation data occur.

In Ref. [5], considering the dense network of residential photovoltaic (PV) systems implemented in Belgium, the paper evaluates the opportunity of deriving global horizontal solar irradiation data from the electrical energy production registered at PV systems. Our results indicate that the accuracy of the derived solar irradiation data depends on a number of factors including the efficiency of the PV system, the weather conditions, the density of PV systems that can be used for the tilt to horizontal conversion, other data sources that can be accessed to complement the PV data.

In Ref. [6], The worldwide growing demand for energy has imposed much pressure on energy supply and the environment. Solar energy, as one of the clean and renewable resources, provides a great potential for helping to meet the growing energy demand and reduce the environmental impacts. How to make the best use of a solar photovoltaic (PV) system has received much attention in recent years. Different orientations and alignment scenarios are incorporated in the model to account for installation constraints while achieving the goal of maximal energy production. The new problem is applied to locate solar PV arrays on a rooftop with limited suitable installation areas.

In Ref. [7], Solar rooftop PV system is an attractive alternate electricity source for households. The potential of solar PV at a given site can be evaluated through software simulation tools. This study is done to assess the feasibility of grid-connected rooftop solar photovoltaic system for a household building in holy city Ujjain, India. The study assesses the energy generation, performance ratio and solar fraction for performance prediction of this solar power plant.

In Ref. [8], The dynamic characteristics of power grids have substantially evolved over the last two decades due to the large-scale integration of power-electronic converter (PEC)interfaced renewable energy sources (RESs). Therefore, the impact of PEC-interfaced RESs on power system stability must be thoroughly examined. This study has shown that solar-PV systems with improved controllers could provide enhanced dynamic reactive power response, hence improve the LTVS.

\section{ELECTRICITY MARKET IN PERU}

\section{A. Electricity generation mix}

The electricity sector of Peru is composed by generation, transmission, distribution, and end-users, as it is normally elsewhere. According to last official reports, as from 2018, electricity was produced mainly by: thermal power plants
(37.82\%), hydropower plants $(57.77 \%)$, solar power plants $(1.47 \%)$, and wind power plants $(2.94 \%)$.

It is important to mention that, in Peru, natural gas became a major player in the generation mix as from 2004 . Before that, the country use to generate electricity by using centralized hydropower plants.

Also, renewable energy, including solar, wind, and others, started to enter into the electricity market in 2010.

Table I shows electric power generation registered in 2018.

TABLE I

\begin{tabular}{|c|c|c|}
\hline \multicolumn{3}{|c|}{ Electric Power Generation by Type in 2018} \\
\hline Type & Energy (GWh) & Participation (\%) \\
\hline Hydropower & $29,357.9$ & 57.77 \\
\hline Thermal & $19,220.0$ & 37.82 \\
\hline Solar & 745.2 & 1.47 \\
\hline Wind & $1,493.6$ & 2.94 \\
\hline Total & $50,816.8$ & 100 \\
\hline
\end{tabular}

Source: Operations Statistics 2018 COES

Thermal power plants are run on different fossil fuels depending on the technology involved. It is important to mention that, in Peru, most of the electricity produced by thermal power plants comes from combined cycle units that run on natural gas.

Table II shows thermal power production by technology in 2018 .

TABLE II

Thermal Power Production by Technology in 2018

\begin{tabular}{|c|c|c|}
\hline Type & Energy $(\mathbf{G W h})$ & $\begin{array}{c}\text { Participation } \\
\mathbf{( \% )}\end{array}$ \\
\hline Combined Cycle & $16,550.4$ & 86.11 \\
\hline Gas Turbine & $2,299.5$ & 11.96 \\
\hline Steam Turbine & 161.6 & 0.84 \\
\hline Diesel Engine & 208.5 & 1.09 \\
\hline Total & $\mathbf{1 9 , 2 2 0 . 0}$ & $\mathbf{1 0 0}$ \\
\hline
\end{tabular}

Source: Operation Statistics in 2018 COES

The following figure highlights the major role played nowadays by combined cycle technologies in the electricity mix of Peru.

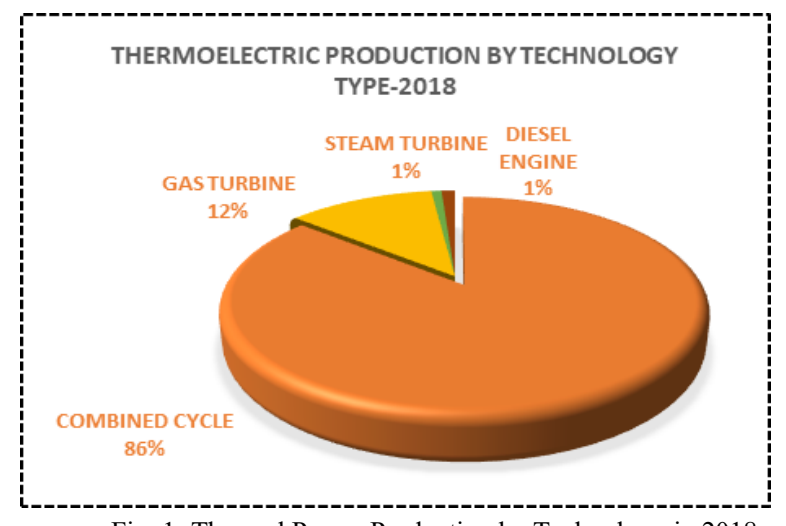

Fig. 1: Thermal Power Production by Technology in 2018 
Energy demand has been increasing in the last decade at a moderate pace. Maximum demand was registered on December 17, 2018 at 19h45. Table III, shows electricity generation used during peak demand.

TABLE III

\begin{tabular}{|c|c|}
\hline \multicolumn{2}{|c|}{$\begin{array}{l}\text { Maximum Demand by Technology Type (Dec. } \\
\qquad 18,2018 \text { at } 19 \mathrm{~h} 45)\end{array}$} \\
\hline TECHNOLOGY TYPE & TOTAL (MW) \\
\hline Hydroelectric & $3,972.2$ \\
\hline Wind & 247.1 \\
\hline Combined cycle & $2,474.2$ \\
\hline Gas turbine & 116.3 \\
\hline Steam turbine & 47.3 \\
\hline Diesel Engine & 27.5 \\
\hline Total & $6,884.6$ \\
\hline
\end{tabular}

Source: Operation Statistics in 2018 COES

Minimum power was registered in January and accounted for 4,025 MW. Maximum power was registered in December and accounted for 6,928 MW. Maximum power during pick hours were registered in December and accounted for 6,885 MW. Total annual energy production reached 50,817 GWh with an overall average load factor of 0.837 . Table IV shows monthly power demand, energy production and load factor for the year 2018.

TABLE IV

\begin{tabular}{|c|c|c|c|c|c|}
\hline \multicolumn{7}{|c|}{ Load Factor in 2018 } \\
\hline Month & $\begin{array}{c}\text { Min } \\
\text { Power } \\
\text { (MW) }\end{array}$ & $\begin{array}{c}\text { Max } \\
\text { Power } \\
\text { (MW) }\end{array}$ & $\begin{array}{c}\text { Max } \\
\text { Power } \\
\text { During } \\
\text { Pick } \\
\text { Hours } \\
\text { (MW) }\end{array}$ & $\begin{array}{c}\text { Energy } \\
\text { Production } \\
\text { (GWh) }\end{array}$ & $\begin{array}{c}\text { Load } \\
\text { Factor }\end{array}$ \\
\hline Jan & 4025 & 6592 & 6489 & 4255.25 & 0.868 \\
\hline Feb & 4582 & 6719 & 6577 & 3919.54 & 0.868 \\
\hline Mar & 4546 & 6670 & 6640 & 4315.87 & 0.870 \\
\hline Apr & 4603 & 6711 & 6711 & 4207.90 & 0.871 \\
\hline May & 4501 & 6617 & 6617 & 4287.98 & 0.871 \\
\hline Jun & 4518 & 6542 & 6542 & 4134.92 & 0.878 \\
\hline Jul & 4286 & 6443 & 6463 & 4200.01 & 0.876 \\
\hline Aug & 4557 & 6519 & 6519 & 4221.87 & 0.870 \\
\hline Sep & 4614 & 6554 & 6554 & 4143.36 & 0.878 \\
\hline Oct & 4622 & 6658 & 6658 & 4354.59 & 0.879 \\
\hline Nov & 4795 & 6786 & 6786 & 4279.41 & 0.876 \\
\hline Dec & 4304 & 6928 & 6885 & 4496.08 & 0.872 \\
\hline Total & $\mathbf{4 , 0 2 5}$ & $\mathbf{6 , 9 2 8}$ & $\mathbf{6 , 8 8 5}$ & $\mathbf{5 0 , 8 1 6 . 7 9}$ & $\mathbf{0 . 8 3 7}$ \\
\hline
\end{tabular}

\section{B. End-use electricity consumption}

According to last official reports, 2017, electricity was consumed mainly by: residential $(21 \%)$, commercial $(17 \%)$, industrial (25\%), and mining (32\%) sectors. All together, they represent approximately $91 \%$ of total electricity consumption in the country.
The following figure shows electricity consumed by different sectors in the year 2017.

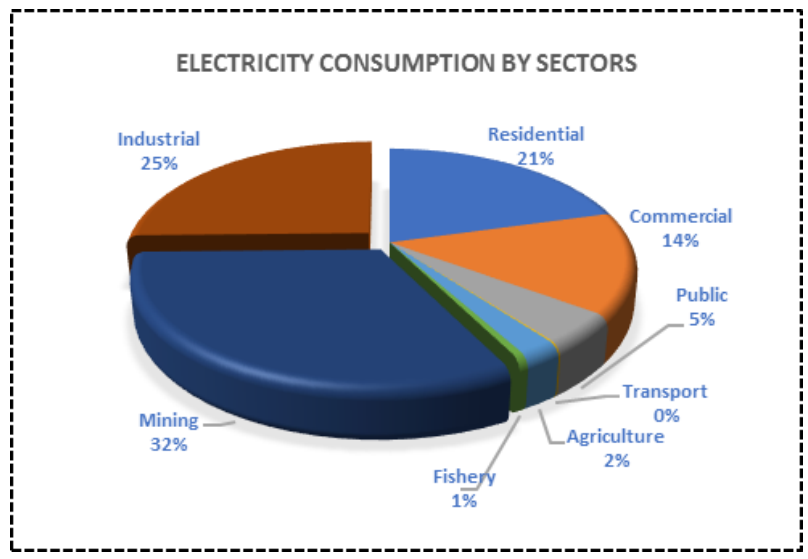

Fig. 2: Electricity consumption by sectors in 2017 Source: National Energy Balance 2017 MINEM

Most of the energy was consumed by the mining sector followed by the industrial and residential sector. Table $\mathrm{V}$ shows electricity consumption by each sector in 2017 .

TABLE V

\begin{tabular}{|c|c|}
\hline \multicolumn{2}{|c|}{ Electricity Consumption by sectors in 2017} \\
\hline Sector & Consumption (GWh) \\
\hline Residential & 9573.4 \\
\hline Commercial & 6741.1 \\
\hline Public & 2106.6 \\
\hline Transportation & 53.1 \\
\hline Agriculture & 1015.9 \\
\hline Fishery & 258.5 \\
\hline Mining & 14946.3 \\
\hline Industrial & 11769.9 \\
\hline Total & 46464.8 \\
\hline
\end{tabular}

Source: National Energy Balance 2017-MINEM

\section{PV ELECTRICITY PRODUCTION AND SOLAR IRRADIATION}

\section{A. Solar PV System}

A $3.25-\mathrm{kWp}$ solar PV system, installed on different university campus located in various regions of Peru, was considered for evaluation purposes. The solar PV system contains PV modules, inverters, controllers, and a monitor. The following figure shows the solar PV system considered for this work.

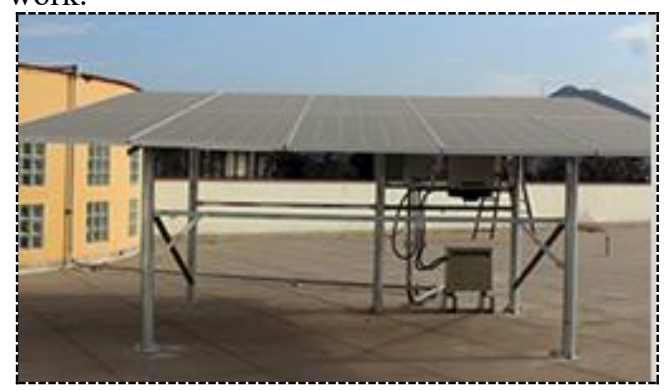

Fig. 3. A 3.25-kWp Solar PV System (Sunny Portal Web) 
Table VI shows technical specification for the PV Module.Canadian Solar Inc. CS6U-325P Model.

TABLE VI

\begin{tabular}{|l|c|}
\hline \multicolumn{2}{|c|}{ Mechanical Data } \\
\hline Specifications & Data \\
\hline Cell Type & Poly-crystalline, 6inch \\
\hline Cell Arrangement & $72(6 \times 12)$ \\
\hline Dimensions & $\begin{array}{c}1960 \times 992 \times 40 \mathrm{~mm} \\
(77.2 \times 39.1 * 1.57 \mathrm{in})\end{array}$ \\
\hline Weight & $22.4 \mathrm{Kg}(49.41 \mathrm{bs})$ \\
\hline Front cover & $3.2 \mathrm{~mm}$ tempered glass \\
\hline Frame material & Anodized aluminum alloy \\
\hline J-Box & IP67,3diodes \\
\hline Cable & $\begin{array}{c}4 \mathrm{~mm} 2 \text { (IEC)OR 4 MM2 \&12AWG } \\
1000 \mathrm{~V}(\mathrm{UL}), 1160 \mathrm{~mm}(45.7 \mathrm{in})\end{array}$ \\
\hline Connector & T4series or PV2 series \\
\hline Per Pallet & 26 pieces, 635 Kg (1400lbs) \\
\hline Per container (40'HQ) & 624 pieces \\
\hline
\end{tabular}

Table VII shows technical specifications for the Inverter. Model Inverter: Sunny Tripower 5000TL-20. Monitor is Sunny Home Manager 2.0.

TABLE VII

\begin{tabular}{|l|c|}
\hline \multicolumn{2}{|c|}{ Technical Data } \\
\hline Input (DC) & Sunny Tripower 5000TL \\
\hline Cell Type & $9000 \mathrm{Wp}$ \\
\hline Cell Arrangement & $1000 \mathrm{~V}$ \\
\hline Dimensions & 245V to 800V/580V \\
\hline Weight & $150 \mathrm{~V} / 188 \mathrm{~V}$ \\
\hline Front cover & $11 \mathrm{~A} / 10 \mathrm{~A}$ \\
\hline Frame material & IP2/A:2; B:2 \\
\hline J-Box & $5000 \mathrm{~W}$ \\
\hline Output (AC) & $5000 \mathrm{VA}$ \\
\hline Rated power (at 230V,50Hz) & $3 / \mathrm{N} / \mathrm{PE} ; 230 / 400 \mathrm{~V}$ \\
\hline Max. AC apparent power & $50 \mathrm{~Hz} /+-5 \mathrm{~Hz}$ \\
\hline Nominal AC voltage & $50 \mathrm{~Hz} / 230 \mathrm{~V}$ \\
\hline AC grid frequency/range & $7.3 \mathrm{~A}$ \\
\hline $\begin{array}{l}\text { Rated power frequency/rated } \\
\text { grid voltage }\end{array}$ & 1 \\
\hline Max,output current & $3 / 3$ \\
\hline Power factor at rated power & $98 \% / 97.1 \%$ \\
\hline $\begin{array}{l}\text { Adjustable displacement } \\
\text { power factor }\end{array}$ & 0.8 overexcited to 0.8 \\
\hline $\begin{array}{l}\text { Feed in phases/connection } \\
\text { phases }\end{array}$ & $\begin{array}{l}\text { underexcited } \\
\text { efficiency }\end{array}$ \\
\hline
\end{tabular}

\section{B. Data Collected}

Information about solar irradiation as well as $\mathrm{PV}$ power output was gathered. Performance Ratio (PR) was calculated based on the solar irradiation and PV power output in each case. Data was collected for five locations, including the cities of Lima (02 sites), Piura, Arequipa, and Pasco. Table VIII shows the five locations considered for the present study.
TABLE VIII

\begin{tabular}{|c|c|c|}
\hline & PV System Site & Location \\
\hline 1 & Lima (MEM) & Central Coast \\
\hline 2 & Lima (UNALM) & Central Coast \\
\hline 3 & Piura & Northern Coast \\
\hline 4 & Arequipa & Southern Coast \\
\hline 5 & Pasco & Central Highland \\
\hline
\end{tabular}

For Site Number 1, Lima (MEM), maximum solar PV production and solar irradiation was registered in March. On the other hand, the minimum values were registered in July. Table IX shows data recorded for this site.

\begin{tabular}{|l|c|c|c|}
\multicolumn{5}{|c|}{ TABLE IX } \\
\hline MONTH & $\mathrm{kW}$ & $\mathrm{W} / \mathrm{m}^{2}$ & $\mathrm{P}$. RATIO (1) \\
\hline JAN & 2,27 & 804,8 & 0,866 \\
\hline FEB & 2,56 & 921,5 & 0,854 \\
\hline MAR & 2,60 & 967,1 & 0,826 \\
\hline APR & 1,87 & 888,8 & 0,648 \\
\hline MAY & 1,12 & 516,6 & 0,666 \\
\hline JUN & 0,77 & 241,5 & 0,983 \\
\hline JUL & 0,69 & 216,0 & 0,983 \\
\hline AUG & 1,23 & 378,2 & 0,997 \\
\hline SEP & 1,56 & 888,8 & 0,539 \\
\hline OCT & 1,74 & 607,0 & 0,885 \\
\hline NOV & 2,09 & 741,2 & 0,866 \\
\hline DIC & 2,14 & 775,0 & 0,849 \\
\hline MAX & 2,60 & 967,09 & 1,00 \\
\hline MIN & 0,69 & 215,97 & 0,54 \\
\hline
\end{tabular}

For Site Number 2, Lima (UNALM), maximum solar PV production and solar irradiation was registered in March. On the other hand, the minimum values were registered in July. Table X shows data recorded for this site.

\begin{tabular}{|l|c|c|c|}
\hline \multicolumn{4}{|c|}{ TABLE X } \\
\hline MONTH & $\mathrm{kW}$ & $\mathrm{W} / \mathrm{m}^{2}$ & $\mathrm{P}$. RATIO (2) \\
\hline JAN & 2,13 & 830,7 & 0,787 \\
\hline FEB & 2,38 & 918,0 & 0,798 \\
\hline MAR & 2,55 & 949,2 & 0,827 \\
\hline APR & 1,71 & 897,1 & 0,587 \\
\hline MAY & 0,70 & 535,7 & 0,403 \\
\hline JUN & 0,92 & 377,6 & 0,749 \\
\hline JUL & 0,62 & 321,2 & 0,590 \\
\hline AUG & 1,28 & 476,2 & 0,830 \\
\hline SEP & 1,68 & 640,9 & 0,806 \\
\hline OCT & 1,83 & 770,8 & 0,731 \\
\hline NOV & 1,62 & 926,0 & 0,539 \\
\hline DIC & 1,10 & 911,1 & 0,372 \\
\hline MAX & 2,55 & 949,21 & 0,83 \\
\hline MIN & 0,62 & 321,18 & 0,37 \\
\hline
\end{tabular}


For Site Number 3, Pasco, maximum solar PV production and solar irradiation was registered in October.

On the other hand, the minimum values were registered in January.

Table XI shows data recorded for this site.

\begin{tabular}{|l|c|c|c|}
\hline \multicolumn{3}{|c|}{ TABLE XI } \\
\hline MONTH & $\mathrm{kW}$ & $\mathrm{W} / \mathrm{m} 2$ & P.RATIO (3) \\
\hline JAN & 2,58 & 975,3 & 0,813 \\
\hline FEB & 2,76 & 1017,8 & 0,833 \\
\hline MAR & 2,79 & 973,4 & 0,883 \\
\hline APR & 2,76 & 917,7 & 0,924 \\
\hline MAY & 2,69 & 881,1 & 0,939 \\
\hline JUN & 2,73 & 849,1 & 0,990 \\
\hline JUL & 2,70 & 861,6 & 0,966 \\
\hline AUG & 2,92 & 980,1 & 0,916 \\
\hline SEP & 2,64 & 940,2 & 0,864 \\
\hline OCT & 2,96 & 1106,1 & 0,824 \\
\hline NOV & 2,77 & 1056,5 & 0,807 \\
\hline DIC & 2,77 & 1074,1 & 0,792 \\
\hline MAX & 2,96 & 1106,09 & 0,99 \\
\hline MIN & 2,58 & 849,09 & 0,79 \\
\hline
\end{tabular}

For Site Number 4, Piura, maximum solar PV production and solar irradiation was registered in August-October. Mayo.

On the other hand, the minimum values were registered in

Table XI shows data recorded for this site.

TABLE XII

\begin{tabular}{|l|c|c|c|}
\multicolumn{3}{|c|}{ TABLE XII } \\
\hline MONTH & $\mathrm{kW}$ & $\mathrm{W} / \mathrm{m}^{2}$ & $\mathrm{P}$. RATIO $(4)$ \\
\hline JAN & 1,85 & 852,0 & 0,668 \\
\hline FEB & 2,08 & 856,0 & 0,749 \\
\hline MAR & 2,36 & 913,1 & 0,794 \\
\hline APR & 2,25 & 910,2 & 0,761 \\
\hline MAY & 1,54 & 836,2 & 0,567 \\
\hline JUN & 1,62 & 843,1 & 0,589 \\
\hline JUL & 2,22 & 886,8 & 0,770 \\
\hline AUG & 2,37 & 924,6 & 0,788 \\
\hline SEP & 2,27 & 909,1 & 0,767 \\
\hline OCT & 1,99 & 970,7 & 0,631 \\
\hline NOV & 1,81 & 909,8 & 0,611 \\
\hline DIC & 1,66 & 880,9 & 0,579 \\
\hline MAX & 2,37 & 970,67 & 0,79 \\
\hline MIN & 1,54 & 836,20 & 0,57 \\
\hline
\end{tabular}

For Site Number 5, Arequipa, maximum solar PV production and solar irradiation was registered in October.

On the other hand, the minimum values were registered in June.

Table XII shows data recorded for this site.

\begin{tabular}{|l|c|c|c|}
\hline \multicolumn{3}{|c|}{ TABLE XII } \\
\hline MONTH & $\mathrm{kW}$ & $\mathrm{W} / \mathrm{m}^{2}$ & $\mathrm{P}$. RATIO (5) \\
\hline JAN & 2,53 & 986,75 & 0,79 \\
\hline FEB & 2,39 & 876,48 & 0,84 \\
\hline MAR & 2,89 & 1018,23 & 0,87 \\
\hline APR & 2,74 & 915,21 & 0,92 \\
\hline MAY & 2,45 & 849,21 & 0,89 \\
\hline JUN & 2,45 & 773,65 & 0,97 \\
\hline JUL & 2,46 & 800,71 & 0,94 \\
\hline AUG & 2,34 & 822,44 & 0,88 \\
\hline SEP & 2,60 & 989,52 & 0,81 \\
\hline OCT & 2,60 & 1085,58 & 0,74 \\
\hline NOV & 2,46 & 1054,86 & 0,72 \\
\hline DIC & 2,42 & 1005,72 & 0,74 \\
\hline MAX & 2,89 & 1085,58 & 0,97 \\
\hline MIN & 2,34 & 773,65 & 0,72 \\
\hline
\end{tabular}

Performance ratios were calculated for all five sites. Average monthly values, calculated for over a year, indicate that highest value corresponds to Site Number 3 (Piura) while the lowest value corresponds to Site Number 2 (Lima UNALM).

The following figure shows monthly variation of performance ratios for the five sited considered in the study.

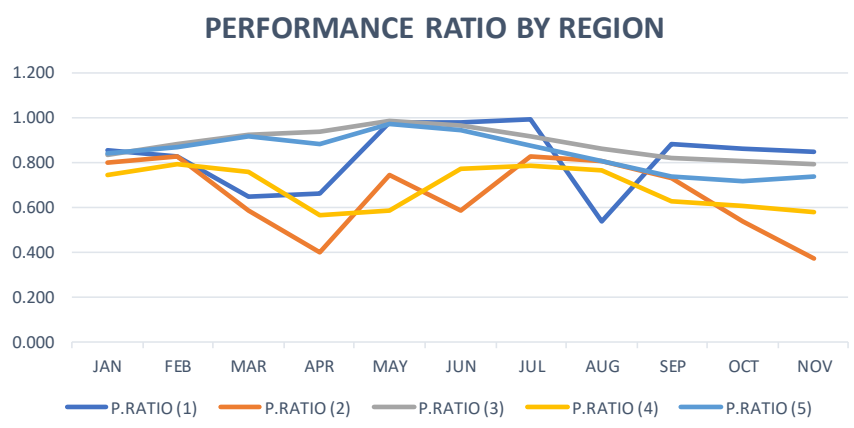

Fig. 4: Monthly Performance Ratio by Region

\section{IMPLICATIONS ON LCOE AND PAYBACK FOR END USERS}

LCOE (US\$ $/ \mathrm{kWh}$ ) calculation depends on solar PV power output over a project life, that usually may be considered around 20 years. It also depends on total implementation cost associated with the implementation of the solar PV system including capital expenses as well as annual operating and maintenance costs.

Table XIII shows average power output for the $3.25-\mathrm{kWp}$ solar PV system as a function of the site where it was installed. 
TABLE XII

Average Daily Solar PV Power Output (kW)

\begin{tabular}{|c|c|c|c|c|c|}
\hline MONTH & $\mathrm{Nr} 1$ & $\mathrm{Nr} 2$ & $\mathrm{Nr} 3$ & $\mathrm{Nr} 4$ & $\mathrm{Nr} 5$ \\
\hline JAN & 2.27 & 2.13 & 2.58 & 1.85 & 2.53 \\
\hline FEB & 2.56 & 2.38 & 2.76 & 2.08 & 2.39 \\
\hline MAR & 2.60 & 2.55 & 2.79 & 2.36 & 2.89 \\
\hline APR & 1.87 & 1.71 & 2.76 & 2.25 & 2.74 \\
\hline MAY & 1.12 & 0.70 & 2.69 & 1.54 & 2.45 \\
\hline JUN & 0.77 & 0.92 & 2.73 & 1.62 & 2.45 \\
\hline JUL & 0.69 & 0.62 & 2.70 & 2.22 & 2.46 \\
\hline AUG & 1.23 & 1.28 & 2.92 & 2.37 & 2.34 \\
\hline SEP & 1.56 & 1.68 & 2.64 & 2.27 & 2.60 \\
\hline OCT & 1.74 & 1.83 & 2.96 & 1.99 & 2.60 \\
\hline NOV & 2.09 & 1.62 & 2.77 & 1.81 & 2.46 \\
\hline DIC & 2.14 & 1.10 & 2.77 & 1.66 & 2.42 \\
\hline AVERAGE & 1.72 & 1.54 & 2.76 & 2.00 & 2.53 \\
\hline
\end{tabular}

From the above table, it can be seen that average highest solar PV power output may be obtained from site Number 3 (Pasco) while lowest solar PV power output would be obtained from site Number 2 (Lima UNALM). If LCOE from site Number 3 is considered as a basis for comparison purposes, LCOE from site Number 2 would be $78.5 \%$ more expensive in terms of US\$/kWh.

Payback time calculation depends on cost savings attributed to electricity produced by the solar PV system that avoids purchasing the same amount of electricity from the local distribution grid. If payback time from site Number 3 is considered as a basis for comparison purposes, payback time from site Number 2 would be $78.5 \%$ longer in time.

\section{CONCLUSIONS}

Solar PV power output is a function of solar irradiation available at the site and it can vary significantly from one place to another. Performance ratio establishes a relationship between the actual and the expected solar PV power output.

In this case, five different sites wherein a 3.25-kWp solar PV system was installed were compared in order to observe the range of monthly variation among the sites.

Performance ratio changes over the year depending on what region the PV system was installed. Considering average monthly values, calculated for over a year, the highest value corresponds to Site Number 3 (Piura) while the lowest value corresponds to Site Number 2 (Lima UNALM).

If LCOE from site Number 3 is considered as a basis for comparison purposes, LCOE from site Number 2 would be $78.5 \%$ more expensive in terms of US $\$ / \mathrm{kWh}$. Also, if payback time from site Number 3 is considered as a basis for comparison purposes, payback time from site Number 2 would be $78.5 \%$ longer in time.

Therefore, expected performance of a solar PV system among different regions of the country is a factor that should be considered when proposing policies and incentives for net metering squemes in distributed generation.

\section{ACKNOWLEDGMENT}

The authors would like to thank the staff members and authorities of the National Agrarian University La Molina, in Lima-Peru, for sharing their time and experience with the research team in order to facilitate data collection. The authors would also like to thank to all the people that, in one way or another, contributed to the present work.

\section{REFERENCES}

[1] SHUVHO, B. et al. 2020. Prediction of solar irradiation and performance evaluation of grid connected solar $80 \mathrm{KWp} \mathrm{PV}$ plant in Bangladesh. Department of Mechanical Engineering, Dhaka University of Engineering \& Technology (DUET), Gazipur, Bangladesh.

[2] THOTAKURA, S. et al. 2020. Operational performance of megawattscale grid integrated rooftop solar PV system in tropical wet and dry climates of India. Department of Electrical Electronics and Communication Engineering, Gandhi Institute of Technology and Management (Deemed to be University), India.

[3] BAHRAMI, A. et al. 2018. The performance and ranking pattern of PV systems incorporated with solar trackers in the northern hemisphere. Department of Mechanical Engineering, Eastern Mediterranean University, Turkey.

[4] MONARCA, U. et al. 2018. Tariff revisions and the impact of variability of solar irradiation on PV policy support: The case of Italy. Department of Economic, University of Foggia, Foggia, Italy.

[5] BERTRAND, C. et al. 2018. Solar irradiation from the energy production of residential PV systems. Royal Meteorological Institute of Belgium, Brussels, Belgium.

[6] ZHONG, Q. et al. 2020 Spatial layout optimization for solar photovoltaic (PV) panel installation. School of Geographical Sciences and Urban Planning, Arizona State University, USA.

[7] DONDARIYA, C. et al. 2018. Performance simulation of grid-connected rooftop solar PV system for small households: A case study of Ujjain, India. Electrical Engineering, Ujjain Engineering College, Ujjain, Madhya Pradesh, India.

[8] MUNKHCHULUUN, E. et al. 2020. Long-term voltage stability with large-scale solar-photovoltaic (PV) generation. Electrical \& Biomedical Engineering, School of Engineering, RMIT University, Melbourne, Australia.

[9] MINISTRY OF ENERGY AND MINES. 2020. Balance Nacional de Energía. Lima, Peru.

[10]COES-SINAC. 2019. Estadística de Operación 2018. Lima, Peru. 